\title{
Biological Activity of Anthraquinone Compounds of the Alcoholic Extract Propolis
}

\author{
Mustafa Abdulkadhim Hussein ${ }^{* 1}$, Hasan Smesam ${ }^{1}$, Lamia Abdultef Risan Al-Iessa ${ }^{1}$, Sareh Arjmand ${ }^{2}$ \\ 1Department of Chemistry, Facuity of science, University of Kufa, Iraq. \\ 2 Protein Research center shahid Beheshti University G. C. Tahran Iran \\ ${ }^{*}$ Corresponding Author Email: Email: mustafa.rabeea@uokufa.edu.iq
}

\begin{abstract}
Different products from a unique Propolis extract, Propolis (bee glue), an of resinous consistency produced by bees, has been used as indigenous medicine for the treatment of several diseases in some contrary. Safety assessment of Propolis extract with respect to antimicrobial activity against three bacterial isolates, Proteus Mirabilis, Klebsiella Pneumonia and Staphylococcus Qureus. The result showed that the main composition of the extract was Anthraquinone, the last one was responsible for biological activity of the extract. FT-IR, UV results showed more than eight peaks for represent the main fine composition of the extract. The present study also showed that the extract has antibacterial activity against three bacterial isolates
\end{abstract}

Key words: Propolis, Soxhlet, Anthraquinone, antibacterial activity, Proteus Mirabilis, Klebsiella Pneumonia, Staphylococcus Qureus.

\section{Introduction}

Propolis(bee glue) is known as complex sticky resin that honeybees[1] collect from plant blooms and then treat it with salivary secretions rich in enzymes to form a compound called Propolis[2,3 ].It is used by bees as an insect repellent and lays the cell from the inside to preserve it and the eggs from insects and diseases. This substance resists the action of some types of bacteria and fungi responsible for the process of decomposition and decomposition through its biological activity [4], Propolis has a distinctive and strong smell because it contains volatile oils, either in terms of consistency and is variable according to temperature, it is solid and easy to break at a temperature $\left(10^{\circ} \mathrm{C}\right)$ and then softens and becomes adhesive At a temperature of $\left(25-45^{\circ} \mathrm{C}\right)$ and at a temperature of $\left(70-60^{\circ} \mathrm{C}\right)$, its strength becomes viscous liquid [5,6,7]. Propolis is a substance soluble in water and organic solvents such as alcohol and ether. The chemical analyzes of Propolis and its components contain phenols, esters, acids, fats, etc. It also contains some mineral elements other than that and it has effectiveness against bacteria, fungi, and viruses $[8,9,10]$. The phenolic acids and gallic acid are the compounds found in higher concentration. However, other Gallic acid derivatives as hydrolysable tannins are present in higher concentrations as compared with other compounds $[11,12,13]$. Flavonoids as Kaempferol, quercetin are also found in Propolis. Concentrations up to $20 \%$ of essential oil can be found in the Propolis [14,15],many reports confirmed the antibacterial, antifungal, antiviral and ant carcinogenic properties of this Propolis [16,17]. Therefore, the purpose of this study was to investigate the chemical composition the extract of Propolis solution by identification of active group of Propolis extract, (FT-IR) and UV- analysis. 


\section{Materials and methods}

1- Preparation of Propolis ethanol extract

The followed method [18] in the work of extracting Propolis, it's called continuous extraction, where grams of Propolis was placed in a thimble and put in Soxhlet the extracted was done by EtOH for 12 hours. The goal of this is to separate the fat from the extract and then filter the extract from the fat and stored for tests.

2- Isolation of Propolis compounds [19]

TLC technology was used to separate [5 ] Propolis compounds and use silica gel sheets $(20 \times 20) \mathrm{cm}$ and $2 \mathrm{~mm}$ thickness [Merck company], mobile phase (BEA) Butanol -Ethanol-Acetic acid and the ratio (5: 4: 1) was used . After Confirm the position of the compounds as in Figure 1, and determine the relative flow rate $\mathrm{R}_{\mathrm{f}}=2$

3- Identification of active group of Propolis extract

Active groups were revealed by TLC technology, The separated Propolis spots were scraped, collected, and dissolved in ethanol. The chemical effective groups were identified in inorganic chemistry laboratory in the Chemistry Department - College of Science - Kufa and the following was [20, 21].

-Sodium Fusible: To small piece of sodium were added drops of Propolis extract in a clean and dried test tube because the sodium is very effective with water, then that heated to be red. 5 drops of ethenol were added and cooled mixture, then heated again to clean sodium. 4-5 mL of distilled water was added to cooled mixture after that boiled again and filtrated. The Propolis Extract Sodium Fusible filtrated solution $\left(\mathrm{PESF}_{\mathrm{fs}}\right)$ was used for the following experiment:

-Nitrogen testing: $2 \mathrm{~mL}\left(\mathrm{PESF}_{\mathrm{fs}}\right)$ was put in a test tube containing 0.1-0.2 gm of $\mathrm{FeSO}_{4}$. The mixture was boiled to convert the Fe II to Fe III then, diluted $\mathrm{H}_{2} \mathrm{SO}_{4}$ was added to produce the blue complex.

-Sulfur testing: The few of $\mathrm{PSF}_{\mathrm{fs}}$ with $\mathrm{CH} 3 \mathrm{COOH}$ and mixed with few drops of $\mathrm{Pb}\left(\mathrm{CH}_{3} \mathrm{COO}\right)_{2}$ to produce black precipitate of $\mathrm{PbS}$.

-Halogens testing: Few drops of $\mathrm{HNO}_{3}$ with $3 \mathrm{ml}$ of the $\left(\mathrm{PESF}_{\mathrm{fs}}\right)$ then mixed with $\mathrm{AgNO}_{3}$ to produce yellow precipitate.

-Phenol testing:Few $\mathrm{mL}$ of $\left(\mathrm{PESF}_{\mathrm{fs}}\right)$ was mixed with few $\mathrm{mL}$ of $\mathrm{FeCl}_{3}$ solution to produce purple solution.

- Aldehydes and Ketones testing:Few $\mathrm{mL}$ of the $\left(\mathrm{PESF}_{\mathrm{fs}}\right)$ was mixed with 3 drops of Brady's reagent the black precipitate indication of positive results of presence of carbonyl group. Also mixed the same amount of volume of $\left(\mathrm{PESF}_{\mathrm{fs}}\right)$ with 3 drops of Fehling's reagent then boiled the mixture for 5 minutes, red precipitate hint of aroma aldehydes. The testing of ketones was done by mixing $1 \mathrm{ml}$ of the $\left(\mathrm{PESF}_{\mathrm{fs}}\right)$ with few drops of sodium nitroprusside to produce red solution [19].

- Anthraquinones testing: Few drops of the $\left(\mathrm{PESF}_{\mathrm{fs}}\right)$ were mixed with $2 \mathrm{~mL}$ of diluted $\mathrm{NaOH}$, the color of solution should be changed from brown to black because the oxidation effect in case of positive result [22].

\section{4-FT-IR Spectroscopy and UV-Spectrum Analysis}

FT-IR (FT-IR-Prestige 21-Shimadzu Spectrophotometer) and UV- spectrum (shimadzu visible 165-UV) analysis were done the biochemical laboratory at the Faculty of Pharmacy, University of Kufa, Najaf, Iraq. 


\section{5-Study the anti-bacterial activity}

Three types of Isolates of bacteria (Proteus Mirabilis, Klebsiella Pneumonia and Staphylococcus Qureus ) were selected to the antibacterial activity .Propolis extract was studied in the laboratories of the Department of Biology - College of Science - University of Kufa ,depending on the following process:

-Preparing the agricultural medium: The media was prepared by Muller_ Hinton Agar according to method [23].

- Anti-bacterial efficacy testing:The diffusion method was followed by using the disc diffusion method, as the paper discs were prepared using a (Whatman no .1) filter paper. Filter papers were cut to circles disc ( $0.5 \mathrm{~cm} \mathrm{Di}$ ) then sterile by autoclave device at a temperature of $121^{\circ} \mathrm{C}$ and pressed 15 pounds / 2 inches for 15 minutes .The disc of papers were dried and submerged in different consternation of the Propolis extract $(1,2,3, \mathrm{~V} / \mathrm{V} \%)$. After 24 hour, the papers were dried by electric oven at temperature $37^{\circ} \mathrm{C}$ for $30 \mathrm{~min}$. Each bacterial isolate was spread onto Muller Hinton agar and left upright for $2 \mathrm{~h}$. The prepared papers were put onto plates and incubated at $37^{\circ} \mathrm{C}$ for $18-24 \mathrm{~h}$. The results were observed by clear zone around the discs [24].

\section{Results and discussion}

\section{Extraction, separation and purification of compounds of alcoholic extract Propolis (Bee glue)}

In this study, the extraction process was worked by the Soxhlet device with ethanol, the method was eliminated[18]. After filtrated the extract was without oil fats. separation process TLC Chromatography technique was used. One spot was observed then it was claw then the chemical components were extracted by dissolved using the ethanol. [25] Alcoholic extraction of Propolis was used in further experiments .

\section{Identification of alcoholic extract of Propolis (Bee glue)}

The identification tests groups of the extract has given good and important results, where the testing of the sulfur, nitrogen and halide groups gave a negative results, this is concordant with 1 . However, testing of phenols, aldehydes and ketones has given a positive results, Anthraquinones new testing is a good because of all researcher were didn't used this test (anthraquinones ) in biological activity [26], it was a positive revelation as the solution became black due to the acute oxidation process [27,28,29]

\section{FT-IR analysis}

Figure 1 showed FT-IR analysis figure, there is a evident and high potent band (3200-3404/cm) which indicate to $\mathrm{OH}$ groups of phenol extract. Another band (1600-1650/cm indicated to ester group C-O or aromatic aldehyde and ketone groups $\mathrm{C}=\mathrm{O}$ which bunch then ring. The band $(1643 / \mathrm{cm})$ which is also the manners match the frequency of the aromatic carbonyl group pertinence to quinine [30,31]. The bands at $1410 / \mathrm{cm}$ illustrated the frequency of manner of aromatic group $\mathrm{C}=\mathrm{C}$, and other strong band $(908$ or $979 / \mathrm{cm})$ which illustrated frequency of manner of group C-O. Another moderate bands at $(651 / \mathrm{cm})$ illustrated the frequency of manner of groups $\mathrm{OH}[32]$. 


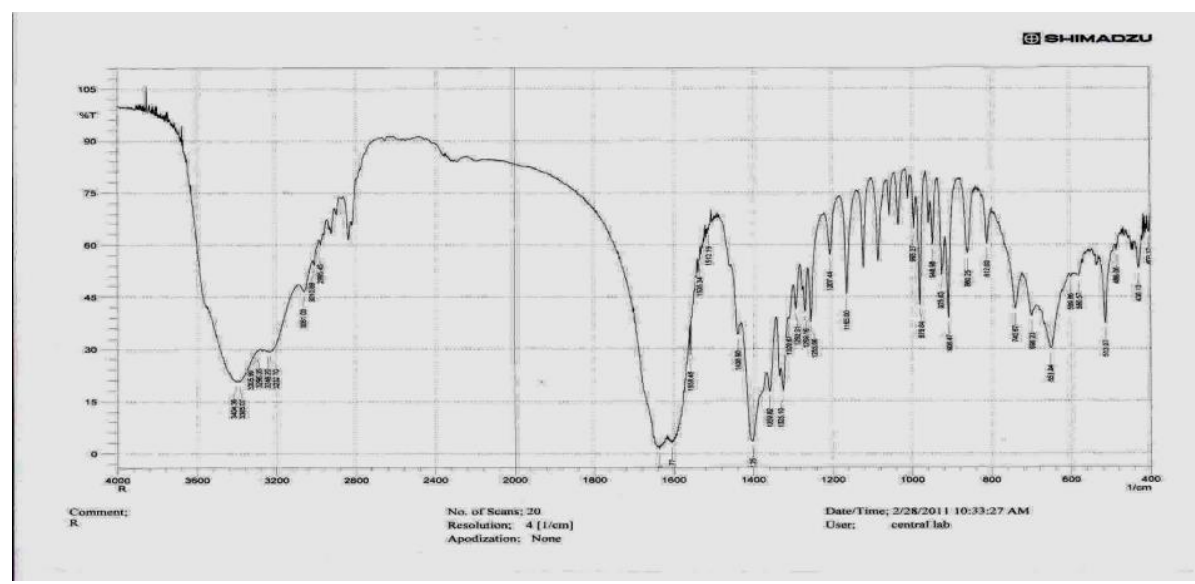

Fig.1 FT-IR analysis of alcoholic extract of PropoliS

\section{UV- Spectrum Analysis}

The results showed of UV- analysisin figure2 for extract of Propolis. The absorption at (219nm) is due to the electronic transfer of type $n-\pi^{*}$ to the phenol group associated with the aromatic ring and absorption from $(281 \mathrm{~nm})$ due to the electronic transmission of type $n-\pi^{*}$ of carbonyl bind with the aromatic ring of the Quinone and absorption of $(342 \mathrm{~nm})$ is due to the $\pi-\pi^{*}$ electronic transmission of the ketone group bind with the aromatic ring [33,34].

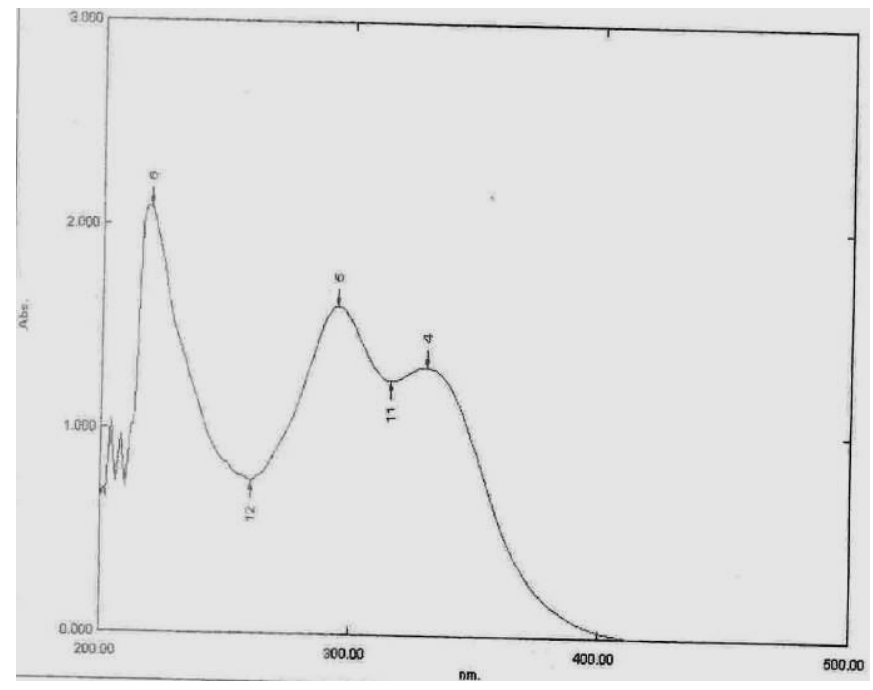

Fig.2 Uv- Spectrum analysis of Propolis extract .

\section{Antibacterial activity of alcoholic extract Propolis}

The results of antibacterial activity of alcoholic extract of Propolis showed by Table 1 against three bacterial isolates, Concentrations of alcoholic extracts were effective in reducing of inhibition present , because of Quinone carbonyl groups were very active of process, why? because of atoms oxygen that the presence of the duple of electronic that react with DNA of Bacteria host, which lead of inhibits the action of effective proteins for bacteria[34,35], also the ketones group has the same work . 
Table.1 Inhibition zone that produced by extract of Propolis

\begin{tabular}{|l|l|l|l|l|}
\hline \multirow{2}{*}{\multicolumn{1}{|c|}{ Bacteria }} & \multicolumn{3}{c|}{ Cons. \% of alcoholic extract Propolis V/V } & \\
\cline { 2 - 6 } & 1 & 2 & 3 & Control \\
\hline K.pneumoia & + & +++ & +++++ & 0 \\
\hline ST.areus & ++ & ++++ & +++++ & 0 \\
\hline P. mirabilis & + & +++ & +++++ & 0 \\
\hline
\end{tabular}

$+=0-6 \mathrm{~mm},++=6-11 \mathrm{~mm},+++=11-17 \mathrm{~mm},+++++=17-25 \mathrm{~mm}$

\section{Conclusion}

This study demonstrated that propolis contains the Quinone group, which inhibited the effectiveness of the bacteria selected for a study with chemical compound groups, where the vital activity of three bacteria was measured after extracting, separating and diagnosing some effective chemical compounds using the alcoholic extract of propolis,

\section{References}

1. Bankova, V.S.; De Castro, S.L.; Marcucci, M.C. Recent advances in chemistry and plant origin. Apidologie 2000, 31, 3-15.

2. Huang, S., Zhang, C.P., Wang, K., Li, G., Hu, F.L., 2014. Recent advances in the chemical composition of propolis. Molecules 19 (12), 19610-19632.

3. Viuda-Martos, M.; Ruiz-Navajas, Y.; Fernández-López, J.; Pérez-Alvarez, J.A. Functional properties of honey, propolis, and royal jelly. J. Food Sci. 2008, 73, R117-R124.

4. Banskota, A.H.; Tezuka, Y.; Kadota, S. Recent progress in pharmacological research of propolis. Phytother. Res. 2001, 15, 561-571.

5. Huang XY, Guo XL, Luo HL, Fang XW, Zhu TG, Zhang XL, Chen HW, Luo LP. Fast Differential Analysis of Propolis Using Surface Desorption Atmospheric Pressure Chemical Ionization Mass Spectrometry. Int J Anal Chem. 2015;2015:176475.

6. Bueno-Silva B, Alencar SM, Koo H, Ikegaki M, Silva GV, Napimoga MH, Rosalen PL. Antiinflammatory and antimicrobial evaluation of neovestitol and vestitol isolated from Brazilian red propolis. J Agric Food Chem. 2013;61(19):4546-50.

7. Lotfy, M., 2006. Biological activity of bee propolis in health and disease. Asian Pac. J. Cancer Prev. APJCP 7 (1), 22-31.

8. Fabio Galeotti 1, Francesca Maccari 1, Alfredo Fachini 2 and Nicola Volpi., Chemical Composition and Antioxidant Activity of Propolis Prepared in Different Forms and in Different Solvents Useful for Finished Products, Foods 2018, 7, 41; doi:10.3390/foods7030041

9. Volpi, N.; Bergonzini, G. Analysis of flavonoids from propolis by on-line HPLC-electrospray mass spectrometry. J. Pharm. Biomed. Anal. 2006, 42, 354-361.

10. Al Mukhlas Fikri a, Ahmad Sulaeman a,*, Ekowati Handharyani b, Sri Anna Marliyati a, Mokhamad Fahrudin., The effect of propolis administration on fetal development, Heliyon 5 (2019) e02672 https://doi.org/10.1016/j.heliyon.2019.e02672.

11. Kustiawan, P.M., Lirdprapamongkol, K., Palaga, T., Puthong, S., Phuwapraisirisan, P., Svasti, J., Chanchao, C., 2017. Molecular mechanism of cardol, isolated from Trigona incisa stingless bee propolis, induced apoptosis in the SW620 human colorectal cancer cell line. BMC Pharmacol. Toxicol. 18, 32 . 
12. Gavanji S, Larki B. Comparative effect of propolis of honey bee and some herbal extracts on Candida albicans. Chin J Integr Med. 2017;23(3):201-7.

13. Huang WY, Cai YZ, Zhang Y. Natural phenolic compounds from medicinal herbs and dietary plants: potential use for cancer prevention. Nutr Cancer. 2010;62(1):1-20.

14. Walker, P., Crane, E., 1987. Constituents of propolis. Apidologie 18, 327-334.

15. Toreti VC, Sato HH, Pastore GM, Park YK. Recent progress of propolis for its biological and chemical compositions and its botanical origin. Evid Based Complement Alternat Med. 2013;2013:697390.

16. Zohreh Ahangari a, Mandana Naseri a, Farzaneh Vatandoost, Propolis: Chemical Composition and Its Applications in Endodontics, Iranian Endodontic Journal 2018;13(3): 285-292

17. Syed Ishtiaq Anjum a, Amjad Ullah a, Khalid Ali Khan b,c, Mohammad Attaullah d, Hikmatullah Khan a, Hussain Ali e, Muhammad Amjad Bashir f, Muhammad Tahir g, Mohammad Javed Ansari h,i, Hamed A. Ghramh b,c,j, Nuru Adgaba h, Chandra Kanta Dash, Composition and functional properties of propolis (bee glue): A review, Saudi Journal of Biological Sciences 26 (2019) 16951703

18. Barre JT, Bowden BF, Coll JC, Dejesus J, Delafuente VE, Janairo GC, Ragasa CY. (1997) A bioactive triterpene from lantana-camara. Phytochemis 45: 321- 324.

19. Deintrop EH. (2007) Applied ThinLayer chromatography, WileyVchVerlag GmbH and Co. KGaA, Weinheim.

20. A.I.Vogle (1958),Elementary Practical Organic Chemistry, Longman Group Limited London

21. Shriner RL, et al. (2004) The systematic identification of organic compounds. John Wiley and Sons. Inc. 8.

22. Hepworth JD, Waring DR, Waring MJ, Berry M, Drayton C. (2002) Aromatic Chemistry, The Royal Society of Chemistry, Cambridge: 176.

23. J.F. Macfadin (1979),Biochemical Test for inditification of medical bacteria ,The Williams and wilkinms and wilkins-CO,U.S.A.

24. Saxena,G;farmer,S; Farmer,S;Hancock,R.e.w g-h -N (1995) Antimicrobial compounds from Anus rubra of pharmcognosy,33(1);33-36.

25. Khalid Abdul Kreem Mohammed, Mustafa Abdulkadhim Hussein, Sawsan I. Noori, Chemical Composition and Anti-bacterial Effects of Clove (Syzygium aromaticum) Flowers, International Journal of Current Microbiology and Applied Sciences Volume 5 Number 2(2016) pp. 483-489.

26. Aronson JK, Phil MAD. (2009) Meyler's side effects of herbal medicines, Oxford, United Kingdom

27. Mistry BD. (2009), A Hand book of Spectroscopic Data Chemistry, OxfordBook CompanyJaipur, India.

28. A.Kar .(2007), Pharmacognosy and Pharmacobiotechnology ,New Age International Publishers,p129-138.

29. G Tojo , M Ferna'ndez.(2002), Oxidation of Alcohols to Aldehydes and Ketones, Springer ScienceBusiness Media, Inc,p208-238.

30. B.D. Mistry.(2009), A Hand book of Spectroscopic Dat $a$ Chemistry, Oxford Book CompanyJaipur, India.

31. Silverstein RM et al. (2005), Spectrometric Identification of organic compounds, John Wiley and Sons. Inc.

32. D Whittaker.(2000), Interpreting Organic Spectra, The Royal Society of Chemistry.

33. R.Anderson and etal.(2004), Organic Spectroscopic Analysis, The Royal Society of Chemistry .p911.

34. S. D. Sarker, L. Nahar.(2007), Chemistry for Pharmacy Students, John Wiley \& Sons Ltd,p142

35. Tojo G, Ferna'ndez M. (2002) Oxidation of alcohols to aldehydes and ketones, Springer ScienceBusiness Media, Inc: 208-238. 